\title{
Journal of FisheriesSciences.com
}

E-ISSN 1307-234X

(c) 2017 Www.fisheriessciences.com

Research Article

\section{Investigation on Feeding, Growth and Condition Factor of Certain Ornamental Fish From Brahmaputra River at Dibrugarh, Assam, India}

\author{
Dibya Jyoti Deori ${ }^{1}$, Santoshkumar Abujam ${ }^{1 *}$, Sanjay Dakua² and Shantikumar Laishram³ \\ ${ }^{1}$ Department of Life Sciences, Dibrugarh University, Assam, India \\ ${ }^{2}$ Department of Biology, Sri Sri Aniruddha Deva Jr. College, Boirangimath, Dibrugarh, Assam, India \\ ${ }^{3}$ Institute of Bioresources and Sustainable Development, Sikkim Centre Gangtok, Dept. of Biotechnology, Govt. of India \\ Received: 14.07.2017 / Accepted: 28.07.2017 / Published: 31.07.2017
}

\begin{abstract}
The investigation has been carried out from different landing site of the Brahmaputra River at Dibrugarh, Assam, India during February, 2014 to January 2015. As a whole, the relative length of gut (RLG) value was found to be highest during pre-monsoon and lowest during winter season. Among the examined species, Trichogaster fasciata was recorded as highest RLG value (5.74) and the lowest (1.10) was recorded in Mystus tengara. The value of RLG reveals that the feeding habit shows a variation from species to species. In case of gastrosomatic index (GSI), out of the examined species, Esomus danricus was found to be the highest (6.5) during pre-monsoon and Osteobrama cotio was lowest GSI (2.32) during winter season. The feeding intensity was found to be more or less similar in all the species. Again, in relation to the growth co-efficient ' $b$ ' of all the examined species, Puntius sophore was recorded as highest ' $b$ ' value (3.31) during monsoon while Osteobrama cotio was recorded as lowest (2.50) during winter season. Further, it predicts that the examined fish species did not follow the cube law and showed the allometric growth. The highest (1.85) condition factor $(\mathrm{K})$ was recorded in $P$. sophore and observed in monsoon. In case of its lowest (1.0) was recorded in Salmostoma bacaila and observed in winter seasons. They were found in health and well-being condition
\end{abstract}

Keywords: Relative length of gut (RLG); Gastrosomatic index (GSI); Growth; Condition factor; Dibrugarh; Assam 


\section{Introduction}

Study of food and feeding habits of fishes have manifold importance in fishery biology. For successful fish farming a thorough knowledge about the food and feeding habit is necessary. Fish like any other organisms depends on the energy received from its food to perform its biological processes such as growth, development, reproduction and other metabolic activities. Detailed data on the diet, feeding ecology and trophic inter-relationship of fishes is fundamental for better understanding of fish life history including growth, breeding, migration (Bal and Rao, 1984). As the nature of food depends to a great extent upon the nature of environment, the problem is interesting from specific, as well as ecological point of view (Bhuiyan et al., 2006).

The study of length weight relationship is one of the important aspects in the study of fish biology. It is one of the important morphometric characters that can be used for taxonomy and ultimately in fish stock assessment. In fishery science, the condition factor or K- factor is used in order to compare the 'condition', 'fatness' or well-being of fish and it is based on the hypothesis that heavier fish of a given length are in better condition (Bagenal and Tesch, 1978). This analysis will reveal the extent to which the two variables, length and weight are related to each other and thereby help one to calculate with ease one variable when the other is known (Chandrika and Balasubramonium, 1986).

Very little works has been done in such aspects of the selected ornamental fishes in north-east India. The length-weight relationship and condition factor of E. danricus from different freshwater environments was investigated (Mustafa, 1976). Again, Nasar and Biswas (1982) studied on the length-weight relationship of Puntius clavatus from Simsang River, Meghalaya. Dakua et al. $(2015,2016)$ studied on length-weight relationship of Esomus danricus and Parluciosoma daniconius from upper Assam. Feeding habit and length-weight relationship of the freshwater spiny eel from the upper Assam were investigated by Abujam et al. $(2013,2014)$ and Abujam and Biswas (2014, 2016). Due to their colour, size and playful behaviour, they are highly rated as aquarium fish in the region. Moreover, the fact that most of these fish species are in high demand not only north east India but also in the rest of India. The present study was carried out with an attempt to evaluate the feeding habit, lengthweight relationship and condition factor of certain ornamental fish species from different lentic and lotic waterbodies in Dibrugarh district of Assam, India.

\section{Materials and Methods}

The fish species for the present investigation have been collected from different landing site of the Brahmaputra River at Dibrugarh, Assam, India during February, 2014 to January 2015. The Dibrugarh district is a plain district of Assam, situated in the Eastern part of Assam which extends from $27^{\circ} 5^{\prime} 38^{\prime \prime} \mathrm{N}$ to $27^{\circ} 42^{\prime} 30^{\prime \prime} \mathrm{N}$ latitude and $94^{\circ} 33^{\prime} 46^{\prime \prime} \mathrm{E}$ to $95^{\circ} 29^{\prime} 8^{\prime \prime} \mathrm{E}$ longitude. For which, 10 different fish species has been selected and different size of each individual were randomly collected. A total number of 1,145 specimens for 10 examined species were used for dissected and calculation of growth coefficient. After washing the specimen were preserved in 5\% formalin for further study. For the study of feeding habit, length-weight relationship and condition factor, total length of the individual fish was measured from the tip of the snout to the extended tip of the caudal fin; total body weight was measured to the nearest $0.1 \mathrm{gm}$ in electronic balance.

\section{Relative length of gut (RLG)}

The alimentary canal of the fish specimen was dissected out, uncoiled it and cleaned off the fat body and other associated gland from the alimentary canal. The extended alimentary canal was then measured in measuring scale followed by taking the weight of the alimentary canal in the electronic weighing balance. The relative gut length is calculated by using the formula of AlHussainy (1949): $\mathrm{RLG}=\mathrm{GL} / \mathrm{TL}$, where, $\mathrm{GL}=\mathrm{Gut}$ length of the fish; $\mathrm{TL}=$ Total length of the fish.

\section{Gastrosomatic index (GSI)}

GSI is calculated by taking the ratio between gut weight and total body weight of the fish specimen and multiplied by 100 (Biswas, 1993).

\section{Length-weight relationship}

The relationship between the total length and the total weight were determined by using the formula as proposed by LeCren (1951): $\mathrm{W}=\mathrm{aL}^{\mathrm{b}}$ where, $\mathrm{W}=$ weight in gram; $\mathrm{L}=$ Total length of the fish specimen in $\mathrm{cm}$; $\mathrm{a}$ and $\mathrm{b}$ is initial growth and growth coefficient respectively. To make the relationship linear, logarithmic transformation of the equation has been adopted as follows: $\log \mathrm{W}=\log \mathrm{a}+\mathrm{b} \log \mathrm{L}$.

\section{Condition factor (K)}

Changes in condition factor $(\mathrm{K})$ or 'ponderal index' has been calculated by using the following formula (Wooton, 1992).

$$
\mathbf{K}=\frac{\mathbf{W} \times 1^{3}}{\mathbf{L}^{3}}
$$

Where; $\mathrm{K}=$ condition factor, $\mathrm{W}=$ Mean weight of the fish ( $\mathrm{g}$ ) and $\mathrm{L}=$ Mean length of the fish $(\mathrm{cm})$. The number $10^{3}$ is a factor to bring the ponderal index $(\mathrm{K})$ to near unity (Carlander, 1970).

\section{Results}

In overall, the mean relative length of gut (RLG) value was found to be highest in most of the examined species during premonsoon and its lowest during winter (Table 1) as in Trichogaster fasciata with the highest (5.74) and lowest (4.21); Puntius sophore with highest (3.04) and lowest (2.88); Esomus danricus with highest (2.60) and lowest (2.48); Osteobrama cotio with highest (1.65) and lowest (1.20); Aspidoparia morar with highest (1.46) and lowest (1.30); Ailia coila with highest (1.33) and lowest (0.91) respectively. In the other species, the highest RLG was observed in monsoon and lowest in winter such as Puntius sarana with highest (2.81) and lowest value (2.50); Salmostoma bacaila with (1.70) and lowest (1.05); Mystus tengara with the highest (1.10) 
and lowest (0.95); Xenentodon cancila with highest (0.93) and lowest (0.56) respectively.

The mean GSI values (Table 2) of $A$. morar was found to be the highest during pre-monsoon (3.32) and lowest during post monsoon (2.80); E. danrica, the highest in pre-monsoon (6.5) and lowest in winter $(6.0) ; P$. sarana with highest in pre monsoon (3.25) and lowest in winter (2.90); P. sophore, the highest in pre monsoon (5.1) and lowest in post monsoon (4.2); S. bacaila, highest in pre monsoon (5.0) and lowest in winter ( 3.58); $O$. cotio, the highest in pre monsoon (3.5) and lowest in winter (2.32); T. fasciata, with highest in monsoon (5.20) and lowest in post monsoon (4.70); A. coila, the maximum in pre monsoon (4.41) and minimum in during winter (3.51); $M$. tengara, with maximum GSI in pre monsoon (3.90) and minimum in winter season (2.51) and $X$. cancila, the highest GSI in pre monsoon (4.35) and lowest in post monsoon (3.90).

The highest mean growth co-efficient (b) in all the examined species was observed during monsoon and lowest during the winter season (Table 3) as in $P$. sophore with highest ' $b$ ' value (3.31) and lowest (3.01); E. danrica with the highest (2.97) and lowest (2.55); X. cancila with highest (2.96) and lowest (2.74); $P$. sarana with highest (2.87) and lowest (2.63); A. coila with highest (2.86) and lowest (2.70); O. cotio with highest (2.80) and lowest (2.50); S. bacaila with maximum (2.75) and minimum (2.53); A. morar with highest (2.74) and lowest (2.51); M. tengara with highest (2.72) and lowest (2.61). In case of $T$. fasciata, the highest mean ' $b$ ' (2.60) during monsoon and lowest (2.53) during winter season.

The mean condition factor $(\mathrm{K})$ of all the fishes was found highest during monsoon whereas lowest value observed during winter season (Table 4). In P. sophore, the highest (1.85) and lowest (1.14) value of ' $\mathrm{K}$ ' were recorded; in $P$. sarana as highest (1.77) and lowest (1.26); in A. morar as highest (1.74) and lowest (1.21); in $X$. cancila as highest (1.71) and lowest (1.01); in $M$. tengara as highest (1.63) and lowest (1.15); in T. fasciata as highest (1.55) and lowest (1.36); in A. coila as highest (1.41) and lowest (1.24); in $O$. cotio as highest (1.36) and lowest (1.11); in $S$. bacaila as highest (1.35) and lowest (1.0); in E. danrica as highest (1.30) and lowest (1.0) respectively.

\section{Discussion}

The mean relative gut length (RLG) of $T$. fasciata, $P$. sophore, E. danrica, O. cotio, A. morar and A. coila was found to be highest during pre-monsoon and its lowest during winter season. Other species like $P$. sarana, $S$. bacaila, $M$. tengara and $X$. cancila was found to be highest during monsoon and lowest during winter season. It reveals that $A$. coila, $M$. tengra and $X$. cancila were fall in carnivorous category; the species like $A$. morar, $E$. danrica, $P$. sarana, $P$. sophore, $S$. bacaila and $O$. cotio were fall in carni-omnivorous category while, $T$. fasciata was being found in herbivorous category. The recorded RLG values also slightly varied from species to species. According to Sinha and Moitra

Table 1: Mean Relative gut length (RLG) of studied fish species.

\begin{tabular}{|c|c|c|c|c|c|}
\hline \multirow{2}{*}{ Sl. no. } & \multirow{2}{*}{ Fish species with numbers } & \multicolumn{4}{|c|}{ Seasons/ Mean RLG value } \\
\hline & & Winter & Pre-monsoon & Monsoon & Post-monsoon \\
\hline 1 & Aspidoparia morar (110 sp.) & $1.30 \pm 0.05$ & $1.46 \pm 0.07$ & $1.40 \pm 0.1$ & $1.36 \pm 0.03$ \\
\hline 2 & Esomus danricus (130 sp.) & $2.48 \pm 0.07$ & $2.60 \pm 0.1$ & $2.55 \pm 0.03$ & $2.50 \pm 0.05$ \\
\hline 3 & Puntius sarana (115 sp.) & $2.50 \pm 0.08$ & $2.71 \pm 0.02$ & $2.81 \pm 0.06$ & $2.60 \pm 0.04$ \\
\hline 4 & Puntius sophore (100 sp.) & $2.88 \pm 0.02$ & $3.04 \pm 0.09$ & $2.95 \pm 0.07$ & $2.90 \pm 0.05$ \\
\hline 5 & Salmostoma bacaila (90 sp.) & $1.05 \pm 0.05$ & $1.67 \pm 0.02$ & $1.70 \pm 0.06$ & $1.50 \pm 0.09$ \\
\hline 6 & Osteobramo cotio (80 sp.) & $1.20 \pm 0.1$ & $1.65 \pm 0.05$ & $1.50 \pm 0.03$ & $1.33 \pm 0.06$ \\
\hline 7 & Trichogaster fasciata (130 sp.) & $4.21 \pm 0.09$ & $5.74 \pm 0.07$ & $5.50 \pm 0.1$ & $4.4 \pm 0.08$ \\
\hline 8 & Ailia coila (140 sp.) & $0.91 \pm 0.02$ & $1.33 \pm 0.05$ & $1.20 \pm 0.07$ & $0.96 \pm 0.04$ \\
\hline 9 & Mystus tengara (120) & $0.95 \pm 0.03$ & $1.01 \pm 0.06$ & $1.10 \pm 0.02$ & $0.98 \pm 0.05$ \\
\hline 10 & Xenentodon cancila (130) & $0.56 \pm 0.04$ & $0.90 \pm 0.07$ & $0.93 \pm 0.05$ & $0.61 \pm 0.08$ \\
\hline
\end{tabular}

Table 2: Mean gastro somatic index (GSI) of studied fish species.

\begin{tabular}{|c|c|c|c|c|c|}
\hline \multirow{2}{*}{ Sl.no. } & \multirow{2}{*}{ Fish species with numbers } & \multicolumn{4}{|c|}{ Seasons/GSI value } \\
\hline & & Winter & Pre-monsoon & Monsoon & Post-monsoon \\
\hline 1 & Aspidoparia morar (110 sp.) & $2.99 \pm 0.14$ & $3.32 \pm 0.26$ & $3.29 \pm 1.24$ & $2.80 \pm 0.92$ \\
\hline 2 & Esomus danricus (130 sp.) & $6.0 \pm 0.18$ & $6.5 \pm 0.15$ & $6.2 \pm 1.0$ & $6.1 \pm 0.81$ \\
\hline 3 & Puntius sarana (115 sp.) & $2.90 \pm 0.11$ & $3.25 \pm 0.19$ & $3.21 \pm 1.12$ & $2.93 \pm 0.75$ \\
\hline 4 & Puntius sophore (100 sp.) & $4.39 \pm 0.15$ & $5.1 \pm 0.20$ & $4.70 \pm 1.01$ & $4.20 \pm 0.62$ \\
\hline 5 & Salmostoma bacaila (90 sp.) & $3.58 \pm 0.13$ & $5.0 \pm 0.22$ & $4.80 \pm 1.06$ & $3.60 \pm 0.84$ \\
\hline 6 & Osteobramo cotio (80 sp.) & $2.32 \pm 0.19$ & $3.5 \pm 0.29$ & $3.43 \pm 1.04$ & $2.40 \pm 0.52$ \\
\hline 7 & Trichogaster fasciata (130 sp.) & $4.9 \pm 0.24$ & $5.1 \pm 0.16$ & $5.20 \pm 1.0$ & $4.70 \pm 0.35$ \\
\hline 8 & Ailia coila (140 sp.) & $3.51 \pm 0.9$ & $4.41 \pm 0.13$ & $4.10 \pm 1.2$ & $3.66 \pm 0.42$ \\
\hline 9 & Mystus tengara (120) & $2.51 \pm 0.14$ & $3.90 \pm 0.18$ & $3.50 \pm 1.27$ & $2.85 \pm 0.71$ \\
\hline 10 & Xenentodon cancila (130) & $4.26 \pm 0.18$ & $4.35 \pm 0.26$ & $4.20 \pm 1.18$ & $3.90 \pm 0.64$ \\
\hline
\end{tabular}


Table 3: Growth coefficient of studied fish species.

\begin{tabular}{|c|c|c|c|c|c|}
\hline \multirow{2}{*}{ Sl. no. } & \multirow{2}{*}{ Fish species with numbers } & \multicolumn{4}{|c|}{ Seasons/ Mean "b" value } \\
\hline & & Winter & Pre-monsoon & Monsoon & Post-monsoon \\
\hline 1 & Aspidoparia morar (110 sp.) & 2.51 & 2.67 & 2.74 & 2.65 \\
\hline 2 & Esomus danricus (130 sp.) & 2.55 & 2.60 & 2.97 & 2.74 \\
\hline 3 & Puntius sarana (115 sp.) & 2.63 & 2.75 & 2.87 & 2.69 \\
\hline 4 & Puntius sophore (100 sp.) & 3.01 & 3.20 & 3.31 & 3.15 \\
\hline 5 & Salmostoma bacaila (90 sp.) & 2.53 & 2.57 & 2.75 & 2.60 \\
\hline 6 & Osteobramo cotio (80 sp.) & 2.50 & 2.54 & 2.80 & 2.67 \\
\hline 7 & Trichogaster fasciata (130 sp.) & 2.53 & 2.55 & 2.60 & 2.56 \\
\hline 8 & Ailia coila (140 sp.) & 2.70 & 2.80 & 2.86 & 2.74 \\
\hline 9 & Mystus tengara (120 sp.) & 2.61 & 2.60 & 2.72 & 2.64 \\
\hline 10 & Xenentodon cancila (130 sp.) & 2.74 & 2.78 & 2.96 & 2.75 \\
\hline
\end{tabular}

Table 4: Mean condition factor $(\mathrm{K})$ of studied fish species.

\begin{tabular}{|c|c|c|c|c|c|}
\hline \multirow{2}{*}{ Sl. no. } & \multirow{2}{*}{ Fish species with numbers } & \multicolumn{4}{|c|}{ Seasons/ Mean condition factor } \\
\hline & & Winter & Pre-monsoon & Monsoon & Post-monsoon \\
\hline 01 & Aspidoparia morar (110 sp.) & $1.21 \pm 0.14$ & $1.43 \pm 0.17$ & $1.74 \pm 0.12$ & $1.60 \pm 0.19$ \\
\hline 02 & Esomus danricus (130 sp.) & $1.0 \pm 0.18$ & $1.25 \pm 0.12$ & $1.30 \pm 0.16$ & $1.10 \pm 0.12$ \\
\hline 04 & Puntius sophore (100 sp.) & $1.14 \pm 0.26$ & $1.20 \pm 0.18$ & $1.85 \pm 0.11$ & $1.71 \pm 0.18$ \\
\hline 05 & Salmostoma bacaila (90 sp.) & $1.0 \pm 0.22$ & $1.10 \pm 0.13$ & $1.35 \pm 0.14$ & $1.23 \pm 0.15$ \\
\hline 08 & Ailia coila (140 sp.) & $1.24 \pm 0.22$ & $1.27 \pm 0.21$ & $1.41 \pm 0.18$ & $1.28 \pm 0.19$ \\
\hline 09 & Mystus tengara (120 sp.) & $1.15 \pm 0.13$ & $1.57 \pm 0.12$ & $1.63 \pm 0.13$ & $1.37 \pm 0.16$ \\
\hline 10 & Xenentodon cancila (130 sp.) & $1.01 \pm 0.22$ & $1.60 \pm 0.29$ & $1.71 \pm 0.24$ & $1.53 \pm 0.20$ \\
\hline
\end{tabular}

(1976) as the fish grow in length there will be a change in food habits from the carnivores to herbivores through omnivorous type and it was also incorporated by Abujam et al. (2013, 2014).

The feeding intensity (GSI) of $A$. morar, $P$. sophore and $X$. cancila were found to be the highest in pre monsoon and lowest in post monsoon. The highest feeding intensity of $E$. danrica, $P$. sarana, S. bacaila, O. cotio, A. coila and M. tengara were found in pre-monsoon and that of lowest in winter while, T. fasciata with highest in monsoon and lowest in post monsoon. Among the examined species, E. danrica, $P$. sophore and $X$. cancila were found to be highest feeding intensity. Generally, feeding intensity is invariably more in pre-monsoon and monsoon while it was decline from post monsoon onwards (Abujam et al., 2013, 2014).

As far as growth co-efficient (b) is concerned, the highest ' $b$ ' values of $P$. sophore, $P$. sarana, E. danrica, X. cancila, A. coila, $O$. cotio, $S$. bacaila, $A$. morar and $M$. tengara were observed in monsoon and that of lowest in the winter season. In case of $T$. fasciata, the highest mean ' $b$ ' was observed during monsoon and lowest during winter. The coefficient ' $b$ ' differs not only in different examined fish species but also differs within the same species depending on sex, maturity stages, feeding intensity etc. However, the ' $b$ ' values of the most fishes were found close to ideal value $(\mathrm{b}=3)$ except $P$. sophore. Hence, they showed the allometric growth in all the seasons. According to Rizvi et al. (2002) the value of ' $b$ ' is generally closely to 3 and may vary between 2.5 and 4.0. However, fish normally do not retain the shape of the body throughout their life span. The reason for the variation are due to seasonal fluctuation in environmental parameter, physiological condition of the fish, sex, gonadal development and nutritive condition of the environment of the fishes (Abujam and Biswas, 2014, 2016).

The condition factor $(\mathrm{K})$ is an indicator of general well-being of the fish. ' $\mathrm{K}$ ' values greater than 1 is an indicative of general well being of the fish good. In this regard, the highest values were observed in monsoon and that of lowest values observed in winter season. It reveals that the examined fishes were found to be healthy and well being in all the seasons. The condition of a fish is influenced by seasonal changes of the gonads and also by the feeding intensity. Scarcity of food or spawning fast might be another reason for the poor condition of the studied fishes.

\section{Conclusion}

From the above discussion, it is concluded that among the studied fishes, E. danrica, T. fasciata, $P$. sophore are herbivorous fish while $P$. sarana is omnivorous fish. $M$. tengara and $X$. cancila was found to be carnivorous fish. Further, it can be concluded that a few of the studied fish species was found to be maintaining its growth. Although in certain fish species the value of " $b$ " was found to be closed to the ideal value 3.0. It can be said that growth of the fishes did follow the ideal value and they were in healthy condition. 


\section{References}

Abujam, S.K.S., Biswas, S.P. (2014) Length-Weight relationship and Condition factor of spiny eel Macrognathus aral from upper Assam, India. Intl J Current Life Sci 4, 605-611.

Abujam, S.K.S., Biswas, S.P. (2016) Length-weight relationship of spiny eel Macrognathus pancalus (Hamilton-Buchanan) from Upper Assam, India. J Aqua Engineering Fish Res 2, 50-60.

Abujam, S.K.S., Shah, R.K., Soram, J.S., Biswas, S.P. (2013) Food and feeding of spiny eel Macrognathus aral (Bloch \& Schneider) from upper Assam. J FisheriesSciences.com 17, 360-373.

Abujam, S.K.S., Soram, J.S., Dakua, S., Paswan, G., Saikia, A.K., et al. (2014) Food and feeding habit of spiny eel Macrognathus pancalus (Ham-Buch) from Upper Assam, India. J Inland Fish Soc India 46, 23-33.

Al-Hussany, A.H. (1949) On the functional morphology of the alimentary tract of some fishes in relation to differences in their feeding habits. Quart J Micr Sci 9, 190-240.

Bagenal, T.B., Tesch, A.T. (1978) Conditions and Growth Patterns in Fresh Water Habitats. Blackwell Scientific Publications, Oxford.

Bal, D.V., Rao, K.V. (1984) Marine fisheries of India. Tata McGraw Hill, New Delhi pp: 296.

Bhuiyan, A.S., Afroz, S., Zaman, T. (2006) Food and feeding habit of the juvenile and adult snakehead Channa punctatus (Bloch). J Life Earth Sci 1, 53-54.

Biswas, S.P. (1993) Manual of Methods in Fish Biology. 2nd edition, South Asian Publishers Pvt. Ltd, New Delhi pp: 65-77

Carlander, D.K. (1970) Handbook of Freshwater Fishery Biology. The Iowa State Univ. Press, Amer. Iowa.
Chandrika, B., Balasubramonium, N.K. (1986) Length-weight relationship of Xenentodon cancila (Ham.) (Teleostei: Belonidae). Proc India Acad Sci 95, 187-190.

Dakua, S., Abujam, S.K.S., Choudhury, P., Biswas, S.P. (2015) Length-Weight relationship of Esomus danricus (Hamilton) from upper Assam, India. Intl J Fish Aqu Studies 2, 125-128.

Dakua, S., Abujam, S.K., Islam M., Basumatary, N. (2016) LengthWeight relationship and Condition factor of Parluciosoma daniconius (Hamilton) from the upper Assam, India. J FisheriesSciences.com 10, 053-056.

LeCren, E.D. (1951) The length-weight relationship and seasonal cycle in gonad weight and condition in perch. J Anim Ecol 20, 201-219.

Mustafa, S. (1976) Selective feeding behaviour of the common carp Esomus danricus (Ham), in its natural habitat. Biol J Linean Soc 8, 279-284.

Nasar, S.A.K., Biswas, S.P. (1982) Studies on the length-weight relationship of Puntius clavatus (McClelland) from Simsang river, Meghalaya, India. Matsya 8, 59-62.

Rizvi, A.F. Nautiyl, P., Deshmukh, V.D. (2002) Comparison of growth in length-weight of Lepturacanthus savala and Eupleurogammus mutics from Mumbai coast. University of Allahabad Studies 1, 57-60.

Sinha, G.M., Moitra, S.K. (1976) Studies on the morpho-histology of the alimentary canal of freshwater fishes of India. I. The alimentary canal of young Cirrhinus reba (Ham.) with a comparison with that of the adult in relation to food. Vestn Spol Zool 40, 221-231.

Wooton, R.J. (1992) Fish ecology. Tertiary Level Biology. Blackies, New York pp: 212. 